\title{
Altman's Z"-Score to Predict Accounting Based Financial Distress of Municipalities: Bankruptcy Risk Map for Metropolitan Municipalities in Turkey
}

\author{
Ali KABLAN iD a \\ a Trakya Üniversitesi, U.U.B.Y.O, Edirne, Türkiye. alikablan@trakya.edu.tr
}

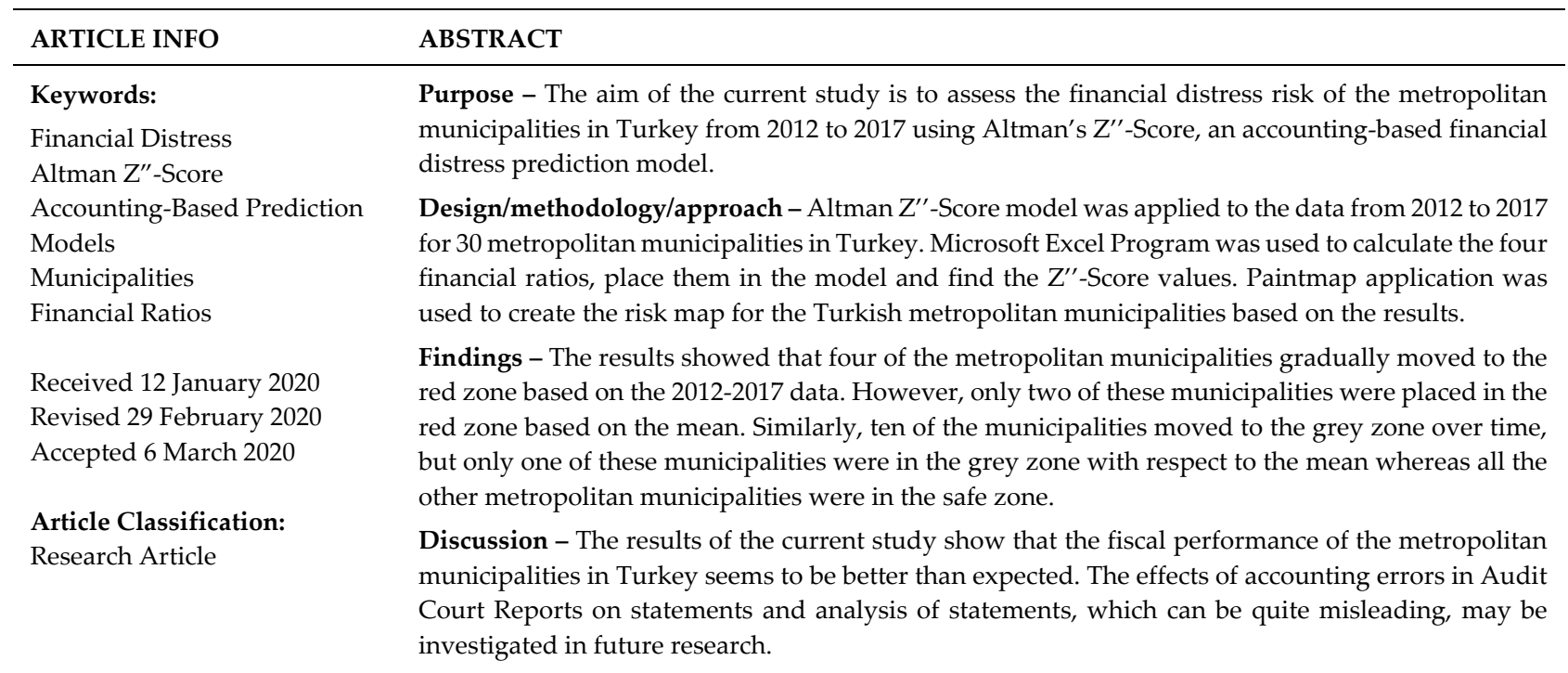

\section{Introduction}

Local administrative bodies are defined as "the public corporate entities established to meet the common local needs of the inhabitants of provinces, municipal districts, and villages, whose decision-making organs are elected by the electorate described in law, and whose principles of structure are also determined by law" in Article 127 of the Turkish Constitution of 1982. As understood from the definition, there are three types of local administration in Turkey, which are special provincial administrations, municipalities and villages.

Municipality is defined as "the means a public entity having administrative and financial autonomy which is established to meet common local needs of inhabitants of a town and whose decision-making body is elected by voters" whereas metropolitan municipality refers to "the a public entity having administrative and financial autonomy which comprises at least three district or first-tier municipalities, coordinates the functioning of such municipalities, discharges its statutory duties, responsibilities and exercises statutory powers, and whose decision-making body is elected by voters" as stated in the Law on Metropolitan Municipalities (No. 5216) in Turkey.

First enacted in 1984, the establishment of metropolitan municipalities is based on the statement "Special administrative arrangements may be introduced for larger urban areas" in the Constitution of 1982, Article 127. The Municipalities of Istanbul, Izmir and Ankara were the first ones to become metropolitan municipalities with the Act on Metropolitan Municipalities (No. 3030) in 1984.

Following that, with "The Establishment of Fourteen Metropolitan Municipalities and Twenty-Seven Districts and Amendments at Certain Law and Decree Laws" (no 6360) published in the Official Gazzette No. 28489 on December $6^{\text {th }} 2012$, the number of the metropolitan municipalities increased from 16 to 29 . Then, Ordu was added to the list making it 30 .

\section{Suggested Citation}

Kablan, A. (2020). Altman's Z"-Score to Predict Accounting Based Financial Distress of Municipalities: Bankruptcy Risk Map for Metropolitan Municipalities in Turkey, Journal of Business Research-Turk, 12 (1), 498-509. 
A. Kablan 12/1 (2020) 498-509

Table 1: Before and After the Enactment of Law No. 6360

\begin{tabular}{|l|l|l|}
\hline Type of Municipalities & Before Law No. 6360 & After Law No. 6360 \\
\hline Metropolitan Municipalities & 16 & 30 \\
\hline Metropolitan District Municipalities & 143 & 519 \\
\hline Province Municipalities & 65 & 51 \\
\hline District Municipalities & 749 & 416 \\
\hline Belde Municipalities & 1977 & 342 \\
\hline Total Number of the Municipalities & 2950 & 1396 \\
\hline
\end{tabular}

Source: https://yerelyonetimler.csb.gov.tr

The efficient use of the resources by local administrative bodies is a current problem in many countries around the world (Balaguer-Coll et al., 2002: 5). The population centering on the cities necessitates the investigation of the municipalities in cities making it of top priority. The evaluation of the efficacy and productivity of the municipalities at the micro-level will contribute to the performance of a country at the macro level as well (Michailov et al., 2002: 3).

Since the enactment of Municipality Law, Metropolitan Municipality Law and Public Finance Management and Control Law in 2005, which was also called "local administration reform", local administrative bodies have become more effective in Turkey. All those laws were guided with the principle of efficient and productive municipalities (Cumhur, 2015: 2). With the enactment of Law No. 5747 to enforce the organizational structure of the municipatilities, the municipalities with financial distress and with less than 2.000 inhabitants have been closed down since 2014 and the provinces with more than 750.000 inhabitants have been turned into metropolitan municipalities, which increased the number from 16 to 30. In addition, the municipalities with more than 50.000 inhabitants have been required to make strategic planning and performance assessment with the enactment of Municipality Law No. 5393.

Financial distress in literature is defined as a condition where a company or individual cannot pay its shortterm obligations and deliver short term commitments with its cash flow that results in taking some measures to get over it (Ross, Westerfield \& Jaffe, 2005: 832). The prediction of financial distress is of utmost importance for both the public and private enterprises as it poses socioeconomic problems for people living in that country. Financial distress prediction models may be of great help for municipalities with administrative decisions while contributing to the effective and productive use of resources (Kulall, 2014: 155). All the metropolitan municipalities in Turkey make up the universe of the study based on the legislations stated above as well as the importance of the subject.

The aim of the current study is to investigate the applicability of financial distress and bankruptcy prediction models with local administrative bodies. For that purpose, financial performance of the metropolitan municipalities in Turkey were reviewed and Z-Score method was used to determine whether they are financially successcul or distressed. Although the municipalities in Turkey are not subjected to bankruptcy, the current study aims to determine their risk of bankruptcy. There are numerous studies on the financial performance of the municipalities. What makes the current study novel in the accounting literature is the lack of research focusing on the bankruptcy risk of municipalities.

\section{Apporaches to Accounting-Based Financial Distress Prediction Models}

Financial distress prediction is one of the weightiest subjects in finance literature where accounting data is used for distinguishing the companies in financial distress or going bankruptcy from the ones which are not (Mahdi \& Abedini, 2009: 399). Financial distress can be predicted with economic, financial, accounting and statistical models. Financial distress prediction models are often divided into two categories, which are 


\section{A. Kablan 12/1 (2020) 498-509}

"accounting-based" and "market-based" models based on the data used. Accounting-based models are used to assess the risk of financial distress by means of the ratios obtained from the statements of companies. These models compares "only one financial ratios" or "multiple financial ratios" to distinguish the companies with financial distress from the ones without it. The availability of financial data has led to the wide use of this method (Outecheva, 2007: 87-88). With the 2005 local administration reforms in Turkey, the cash basis government accounting was changed into accruals accounting, which make statements eligible for analysis.

Accounting-based financial distress prediction models focuses on the financial ratios, are divided into two groups based on the number of independent variables, which are univariate and multivariate models. In addition, Beaver (1966) followed by Altman (1968) are known as the first researchers to make an empirical study of financial distress (Kulal1, 2014: 158).

In his famous work on financial distress prediction, Beaver investigated 79 companies with financial distress and 79 financially successful companies using his financial distress prediction model. Beaver studied the success of accounting ratios for predicting bankruptcies of firms and found out that the ratios of failed firms were worse than the successful firms for five years prior to bankruptcy. In other words, the difference in the financial ratios between the succesful and failed firms emerged at least five years before the financial distress (Sakız, 2017: 283). Beaver's model predicted the financial distress with an error margin of $22 \%$ and estimated the successful ones with an error margin of $5 \%$. The error margin is likely to increase as the default date approaches (Outecheva, 2007: 89). According to Beaver (1966), financial failure is being unable to pay it liabilities (Özdemir, 2014: 150). Beaver proposed five ratios to forecast financial distress or bankruptcy (Sayllgan, 2008: 408), which are;

- Net Cash Flow / Total Liabilities

- Net Income / Equity

- Working Assets / Short Term Liabilities

- Total Liabilities / Equity

- Working Capital / Equity

Building on the work of Beaver, Edward Altman (1968) developed a slightly different prediction model using financial ratios which aimed to eliminate the weaknesses of univariate model. The original multiple linear discrimant based Z-Score model developed by Altman (1968) has been regared as the first multivariate financial distress prediction model (Bemmann, 2005: 69). These models assume a linear relationship between each of the rational variables and the probability of financial failure (Miller, 2009: 4). The Discriminant function is used to construct the linear combination of independent variables, or the financial ratios and transform all these variables into a single discriminant value. Based on the Z-Score, it is possible to predict financial distress. If the Z-Score is above (on the right) of the critical value, then the company is successful. If it is below (on the left of) the critical value, then it represent a company in distress (Sakız, 2017: 285).

During the period of 1946-1965, Altman studied 66 firms whose assets sized at least 1 million dollars each. Thirty-three of the firms went bankcruptcy while the rest 33 did not declare bankruptcy. He constructed five different financial categories to predict financial distress of the firms. Based on the correlation between the variables and the contribution of the independents variables to the model, the original 22 financial ratios were reduced to 5, which are profitability, liquidity, leverage, solvency and operations (Outecheva, 2007: 90). The Z-Score model is made up of 7 basic values, 6 of which are accounting-based and 1 of which is market-based. All of the values are covered by 5 selected ratios. The formulation of the model (Altman, 2000: 9) where the financial ratios are multiplied by the coefficients are as follows;

$\mathrm{Z}-$ Score $=1.2 \mathrm{~T} 1+1.4 \mathrm{~T} 2+3.3 \mathrm{~T} 3+0.6 \mathrm{~T} 4+0.999 \mathrm{~T} 5$

- $\mathrm{T1}=$ Working capital / Total assets

- $\mathrm{T} 2=$ Retained earnings / Total assets

- T3= Earnings before interests and taxes / Total assets 
- T4= Market value of equity / Book value of total debt

- $\mathrm{T} 5=$ Sales $/$ Total assets

If Z-Score is;

- $\mathrm{Z}>2.99$, then, the firm is in the "safe" zone,

- $1.81<Z<2.99$, then the firm is in the "grey" zone,

- $\mathrm{Z}<1.81$, then the firm is in the "distress" zone.

Altman's Z-Score model was found to be $94 \%$ accurate in predicting failure one year before the bankruptcy while it was $72 \%$ accurate two years before the event. Three, four and five years before the failure, the accuracy was found to be $48 \%, \% 29 \%$ and $36 \%$, respectively, which shows that the accuracy of the model reduces significantly for predicting the bankruptcy three or more years before it takes place (Altman, 1968).

Table 2. Financial Ratios Used in Beaver and Altman Financial Distress Models

\begin{tabular}{|c|c|}
\hline 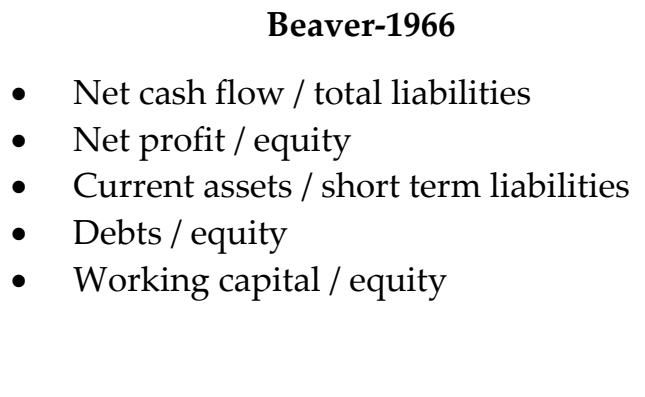 & \begin{tabular}{ll}
\multicolumn{1}{c}{ Altman-1968 } \\
- & Working capital / total assets \\
- & Retained earnings / total assets \\
- & Earnings before interest and taxes / total \\
- & Marsets \\
- & Sotal debt \\
- & Sales / total assets
\end{tabular} \\
\hline
\end{tabular}

It is worth noting that all the ratios were used for manufacturing companies, which makes them inapplicable to other firms, such as transportation companies. There are also uncertainties about the market value of the shares in non-public companies (Outecheva, 2007: 91). After receiving some criticism for that, Altman revised his model to suit the needs of private firms with Z'-Score and non-manufacturer and service firms with Z'Score (Altman, 2000:14). With his revised Z'-Score/Z"-Score models, Altman replaced the market value of equity with the book value, which made it possible for the non-public companies to use the model as well. $Z^{\prime}$ Score and Z"-Score formulas (Altman, 2000: 25) are as follows;

T4= Market value of equity / Book value of total debt ratio in the original Z-Score model was replaced by T4= Book value of equity / Book value of total debt, which yielded the following model (Altman, 2000: 25-26):

$Z^{\prime}$-Score $=0.717 T 1+0.847 T 2+3.107 T 3+0.42 T 4+0.998 T 5$ (for private firms)

If $Z^{\prime}$-Score is,

- Z'>2.9 then, the firm is in the "safe" zone,

- $1.23<Z$ ' $<2.9$ then the firm is in the "grey" zone,

- $Z^{\prime}<1.23$ then the firm is in the "distress" zone.

In his Z"'-Score model, Altman (2000) made some changes to predict financial failure in non-manufacturer service companies. In order to minimize the effects of potential industry T5= Sales / Total assets ratio was removed to make an accurate prediction unaffected by types of businesses. With this revision, the cut-off value to determine financial failure was updated to 1.10 whereas the $Z^{\prime \prime}$-Score should be at least 2.60 for successful firms. The Z'-Score model (Hayes et al., 2010: 125-126) for those firms are shown below; 
$Z^{\prime \prime}-$ Score $=6.56 \mathrm{~T} 1+3.26 \mathrm{~T} 2+6.72 \mathrm{~T} 3+1.05 \mathrm{~T} 4$ (For service companies)

If $Z^{\prime \prime}$-Score is,

- Z">2.6 then, the firm is in the "safe" zone,

- $1.1<Z$ " $<2.6$ then, the firm is in the "grey" zone,

- $Z$ " $<1.1$ then, the firm is in the "distress" zone.

Table 3. Altman Z-Score Ranges

\begin{tabular}{|l|l|l|}
\hline \multicolumn{1}{|c|}{$Z$-Score (Public Companies) } & $\begin{array}{l}\text { Z'-Score (Industrial Companies) } \\
\text { (Public or Nonpublic Companies) }\end{array}$ & Z"-Score (Service Companies) \\
\hline $\begin{array}{l}Z<1,8 \text { Area with Bankruptcy } \\
\text { Risk }\end{array}$ & $\begin{array}{l}Z^{\prime}<1,23 \text { Area with Bankruptcy } \\
\text { Risk }\end{array}$ & $\begin{array}{l}Z^{\prime \prime}<1,1 \text { Area with Bankruptcy } \\
\text { Risk }\end{array}$ \\
\hline $1,8<Z<2,99$ Uncertain Area & $1,23<Z^{\prime}<2,9$ Uncertain Area & $1,1<Z^{\prime \prime}<2,6$ Uncertain Area \\
\hline$Z>2.99$ Safe Area & $Z^{\prime}>2,9$ Safe Area & $Z^{\prime \prime}>2,6$ Safe Area \\
\hline
\end{tabular}

Source: (Hauschild, 2013: 6).

The Z/Z'/Z"-Score models developed by Altman is widely used by many institutions and organizations for early warning for financial failure, financial risk assessment and rating systems as it helps creditors and investors to make right decisions (Hauschild, 2013: 7).

\section{Literature Review}

Most of the literature on the prediction of financial failure seems to focus on large-scale private businesses or non-public ones. To the best of the author's knowledge, the number of the studies on the use of Z-Score model to predict financial failure of local administrative bodies is still scarce with no studies in Turkey and a few in the world. The reason is often that the financial reporting is treated differently in local administations and private businesses. What makes the current study novel is that the municipalities in Turkey and some countries around the world are not subjected to bankruptcy. The related research is presented below.

In his work on municipal default and hedge fund strategy, Unercoffer (2013) found the Z"-Score (Z"-Score = $6.56 \mathrm{~T} 1+3.26 \mathrm{~T} 2+6.72 \mathrm{~T} 3+1.05 \mathrm{~T} 4)$ value to ve 2.71 for City of Detroit. It is interesting that Unercoffer used a range $(1.10<Z$ " $<2.9)$ different from that of Altman (2000), who calculated the $Z^{\prime \prime}$-Score range as $1.1<Z$ " $<2.6$ for service companies.

Fisher, Marsh and Bunn (2015) investigated the fiscal health of Texas and its municipalities using the revised Altman Z-Score with the government's annual financial report data. The findings showed that Austin (2.754), along with the major cities of Dallas (2.841) and San Antonio (1.601), are in the grey zone whereas Sealy (0.627) is found in the distressed zone. On the other hand, the state of Texas has a Z-Score (4.665) considered in the safe zone the state of Texas has a Z-Score (4.665) considered in the safe zone. It is interesting the range used is $\left(1.10<Z^{\prime \prime}<2.9\right)$ different from that of Altman (2000), who calculated the $Z^{\prime \prime}$-Score range as $1.1<Z^{\prime \prime}<2.6$ for service companies.

Gunnlaugsson (2017) studied the credit risk of Icelandic municipalities using Altman's Z'-Score model. The relationship between financial health and the size of municipalities was also examined. The results showed that Icelandic municipalities were going through some financial problems. Relatively small municipalities (3.32) were stronger than the larger ones (1.05) on average.

\section{The Aim of the Study and Method}

The aim of the current study is to investigate the applicability of financial distress and bankruptcy prediction models, which are frequently used in private businesses, with local administrative bodies. For that purpose, 
the financial distress risk of the metropolitan municipalities in Turkey were assessed using Altman Z'-Score method, an accounting-based financial distress model. The model was applied to the data from 2012 to 2017 from 30 metropolitan municipalities in Turkey. In order to calculate the Z-Score, content analysis was employed for the qualitative date in audit reports of the metropolitan municipalities. Financial status of the metropolitan municipalities was investigated with the financial distress prediction models and risks maps were created to visualize the results.

\section{The Sample of the Study and Dataset}

The universe of the study is made up of the metropolitan municipalities in Turkey which were auidet by the Court of Accounts and which announced the audit reports to the public. The study included all the universe based on the audit report during 2012-2017 released by the Court of Accounts. The data were obtained from the audit reports of Court of Accounts for metropolitan municipalities. The statements of the municipalities were retrieved from Court of Accounts' database including all of the metropolitan municipalities in Turkey. In order to calculate the Z'-Score for the municipalities, budget data, balance sheets and operating results were analyzed. Altman's Z"-Score for the municipalities were found with the placement of 4 financial ratios in the model. 696 observations were made to apply Altman's revised Z''-Score model during the period from 2012 to 2017. The study started in 2012 with the release of the reports. However, 2018 reports were not included in the study as they were not released during the time the current study was being conducted. Within this framework, a total of 174 Z''-Scores were presented for 30 Metropolitan Municipalities.

In Turkey, there are a total of 30 metropolitan municipalities and 81 provinces in Turkey. These cities governed by the metropolitan municipalities make up $52 \%$ of the surface area of the Turkey while their populations make up $\% 77$ of the total population (Hergüner, 2017: 634). The list of the metropolitan municipalities included in the sample are presented in Table 4.

Table 4. The Metropolitan Municipalities in Turkey in 2019

\begin{tabular}{|l|l|l|}
\hline - Metropolitan Municipality of Adana & - Metropolitan Municipality of Kayseri \\
- Metropolitan Municipality of Ankara & - Metropolitan Municipality of Kocaeli \\
- Metropolitan Municipality of Antalya & - Metropolitan Municipality of Konya \\
- Metropolitan Municipality of Aydın & - Metropolitan Municipality of Malatya \\
- Metropolitan Municipality of Bursesir & - Metropolitan Municipality of Manisa \\
- Metropolitan Municipality of Denizli & - Metropolitan Municipality of Mardin \\
- Metropolitan Municipality of Diyarbakır & - Municipality of Mersin \\
- Metropolitan Municipality of Erzurum & - Metropolitan Municipality of Muğla \\
- Metropolitan Municipality of Eskişehir & - Metropolitan Municipality of Ordu \\
- Metropolitan Municipality of Gaziantep & - Metropolitan Municipality of Samsun \\
- Metropolitan Municipality Hatay & - Metropolitan Municipality of Şanliurfa \\
- Metropolitan Municipality İstanbul & - Metropolitan Municipality of Tekirdağ \\
- Metropolitan Municipality İzmir & - Metropolitan Municipality of Trabzon \\
& Kahramantan Municipality of & \\
\hline
\end{tabular}

Source: (https://www.blogarti.com/turkiyenin-buyuksehirleri.html)

\section{Research Model}

Altman's revised Z"'-Score model for predicting financial failure was applied to the data from 2012 to 2017 for 30 metropolitan municipalities in Turkey. Microsoft Excel Program was used to calculate the four financial ratios, place them in the model and find the $\mathrm{Z}^{\prime \prime}$-Score values. Paintmap application was used to create the risk map for the Turkish metropolitan municipalities based on the results.

In order to apply the formula Z"-Score $=6.56 \mathrm{~T} 1+3.26 \mathrm{~T} 2+6.72 \mathrm{~T} 3+1.05 \mathrm{~T} 4$, the following ratios were used based on the statements of Metropolitan Municipalities as stated in the audit reports;

Working assets / Total assets ratio was used as T1 variable 
A. Kablan 12/1 (2020) 498-509

$\checkmark$ Retained earnings / Total assets ratio was used as T2 variable. By the nature of municipalities' financial statements, Previous Years' Positive Operating Results was taken as the reference for Retained Earnings.

$\checkmark$ Earnings before interest and taxes / Total assets ratio was used as T3 variable. By the nature of municipalities' financial statements, Operating Results was taken as the reference for Earnings before interest and taxes.

$\checkmark$ Book value of equity / Book value of total debt was used as T4 variable.

The Z'-Score values for metropolitan municipalities were categorized based on Altman's reference range for Z'-Score. The municipalities were placed in Red Area, Grey Area and Green Area based on their financial failure risks, which are presented in Table 5.

Table 5. Z"-Score Ranges

\begin{tabular}{|ll|}
\hline Z"-Score \\
\hline$Z^{\prime \prime}<1,1$ Area with Bankruptcy Risk & (Identified as Red Zone) \\
\hline $1,1<Z "<2,6$ Uncertain Area & (Identified as Grey Zone) \\
\hline$Z^{\prime \prime}>2,6$ Safe Area & (Identified as Green Zone) \\
\hline
\end{tabular}

\section{Findings}

The results showed that four of the metropolitan municipalities gradually moved to the red zone based on the 2012-2017 data. However, only two of these municipalities were placed in the red zone based on the mean. Similarly, ten of the municipalities moved to the grey zone over time, but only one of these municipalities were in the grey zone with respect to the mean whereas all the other metropolitan municipalities were in the safe zone. The findings are presented in Table 6.

Table 6. Z"-Scores from 2012 to 2017

\begin{tabular}{|c|c|c|c|c|c|c|c|}
\hline & $\begin{array}{c}2012 \\
\text { Z"Score }\end{array}$ & $\begin{array}{c}2013 \\
\text { Z"Score }\end{array}$ & $\begin{array}{c}2014 \\
\text { Z"Score }\end{array}$ & $\begin{array}{c}2015 \\
\text { Z"Score }\end{array}$ & $\begin{array}{c}2016 \\
\text { Z"Score }\end{array}$ & $\begin{array}{c}2017 \\
\text { Z"Score }\end{array}$ & $\begin{array}{l}\text { Ortalama } \\
\text { Z"Score }\end{array}$ \\
\hline Adana M.M. & - & 0,489 & 0,626 & $-0,054$ & 0,116 & 0,361 & 0,307 \\
\hline Ankara M.M. & - & 8,032 & 6,954 & 8,448 & 8,618 & 7,437 & 7,898 \\
\hline Antalya M.M. & - & - & 4,967 & 6,266 & 5,192 & 3,328 & 4,938 \\
\hline Aydın M.M. & - & - & 11,137 & 9,269 & 6,443 & 6,297 & 8,287 \\
\hline Balıkesir M.M. & - & - & 9,995 & 9,486 & 5,736 & 2,774 & 6,998 \\
\hline Bursa M.M. & 3,299 & 3,000 & 3,681 & 2,940 & 2,475 & 2,838 & 3,108 \\
\hline Denizli M.M. & - & - & 10,151 & 4,900 & 3,440 & 1,871 & 5,090 \\
\hline Diyarbakır M.M. & 5,988 & 5,171 & 18,296 & 22,826 & 27,744 & 31,292 & 18,553 \\
\hline Erzurum M.M. & 5,530 & 6,44 & 5,630 & 2,087 & $-0,244$ & $-0,313$ & 3,189 \\
\hline Eskişehir M.M. & 2,726 & 1,981 & 2,254 & 2,519 & 2,540 & 3,869 & 2,648 \\
\hline Gaziantep M.M. & 7,659 & 6,117 & 5,439 & 3,442 & 2,342 & 2,673 & 4,612 \\
\hline
\end{tabular}


A. Kablan 12/1 (2020) 498-509

\begin{tabular}{|c|c|c|c|c|c|c|c|}
\hline Hatay M.M. & - & - & 8,054 & 8,360 & 6,205 & 3,889 & 6,627 \\
\hline İstanbul M.M. & - & 8,323 & 8,979 & 8,045 & 2,511 & 4,915 & 6,554 \\
\hline İzmir M.M. & - & 10,580 & 9,972 & 10,022 & 8,754 & 6,377 & 8,499 \\
\hline KahramanmaraşM.M. & - & - & 7,226 & 5,914 & 4,720 & 1,741 & 4,900 \\
\hline Kayseri M.M. & - & 2,998 & 3,174 & 3,564 & 3,161 & 2,432 & 3,066 \\
\hline Kocaeli M.M. & - & 2,717 & 1,893 & 2,161 & 2,157 & 2,359 & 2,257 \\
\hline Konya M.M. & 9,476 & 3,864 & 2,902 & 3,244 & 3,549 & 2,859 & 4,315 \\
\hline Malatya M.M. & - & - & 5,404 & 4,722 & 3,547 & 3,624 & 4,324 \\
\hline Manisa M.M. & 9,421 & 5,604 & 9,037 & 6,402 & 5,039 & 3,410 & 6,486 \\
\hline Mardin M.M. & - & - & 10,868 & 9,539 & 8,369 & 6,102 & 8,719 \\
\hline Mersin M.M. & - & 6,312 & 8,546 & 7,502 & 4,690 & 2,913 & 5,993 \\
\hline Muğla M.M. & - & - & 10,112 & 23,224 & 28,888 & 10,091 & 18,079 \\
\hline Ordu M.M. & - & - & 2,529 & 2,575 & 1,537 & 8,641 & 3,820 \\
\hline Sakarya M.M. & - & 3,191 & 4,145 & 4,374 & 3,830 & 3,352 & 3,778 \\
\hline Samsun M.M. & 1,610 & $-0,673$ & $-0,239$ & $-0,491$ & $-0,800$ & 0,016 & $-0,096$ \\
\hline Şanlıurfa M.M. & - & - & 4,624 & 7,352 & 11,571 & 7,115 & 7,665 \\
\hline Tekirdağ M.M. & - & - & 8,319 & 9,213 & 6,354 & 6,166 & 7,513 \\
\hline Trabzon M.M. & - & - & 1,317 & 5,717 & 5,060 & 5,567 & 4,415 \\
\hline \multirow[t]{2}{*}{ Van M.M. } & - & - & \multirow[b]{2}{*}{8,296} & \multirow[b]{2}{*}{6,791} & \multirow[b]{2}{*}{5,834} & \multirow[b]{2}{*}{4,061} & \multirow[t]{2}{*}{6,246} \\
\hline & & & & & & & \\
\hline
\end{tabular}

\subsection{The Review of 2014 Z"'-Scores}

Z"-Scores of 2014 show that 2 of the 30 metropolitan municipalities were in financial distress (Red Area) whereas 4 municipalities were in the grey area and 24 municipalities were in the safe zone (Green Area). The risk map for 2014 is shown below. 


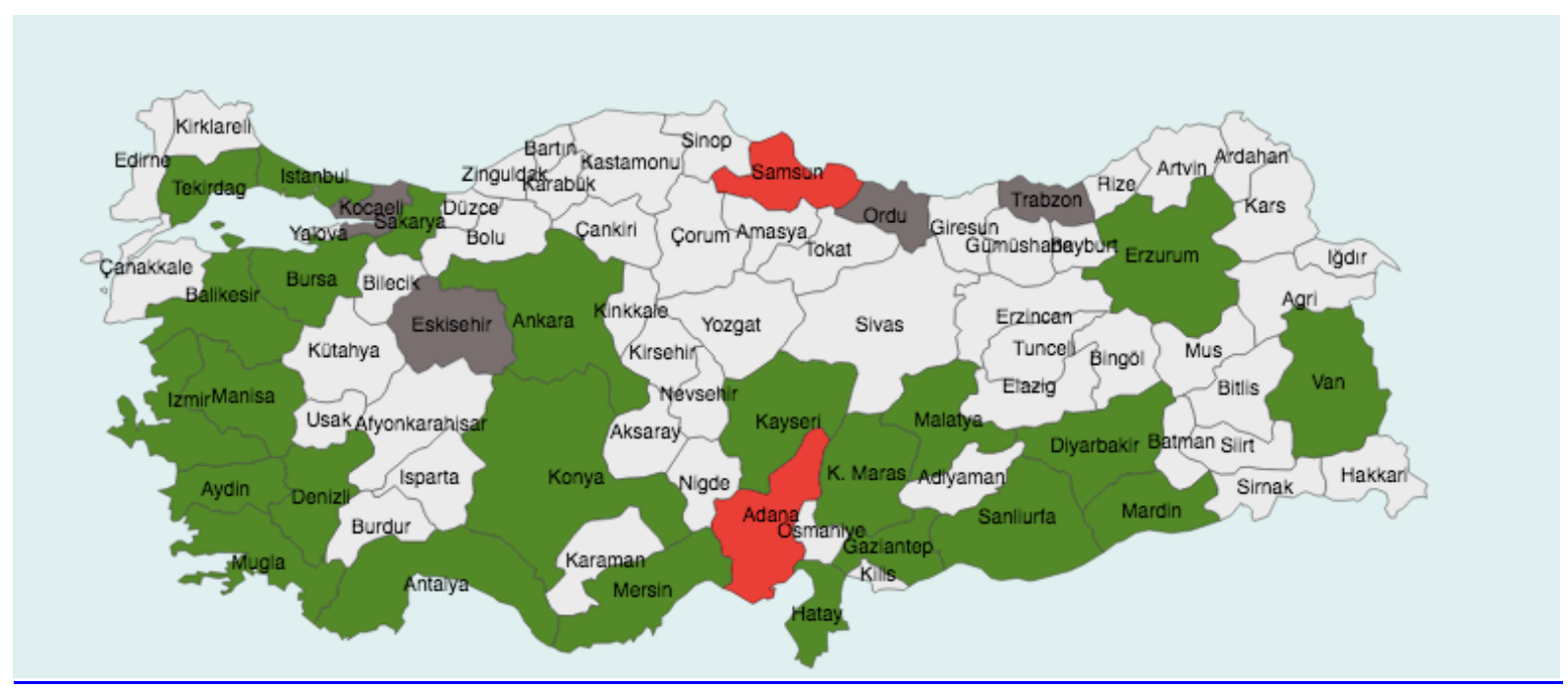

Map 1: Risk Map for the Metropolitan Municipalities in 2014

\subsection{The Review of 2015 Z'-Scores}

Z"-Scores of 2015 show that 2 of the 30 metropolitan municipalities were in financial distress (Red Area) whereas 4 municipalities were in the grey area and 24 municipalities were in the safe zone (Green Area). The risk map for 2015 is shown below.

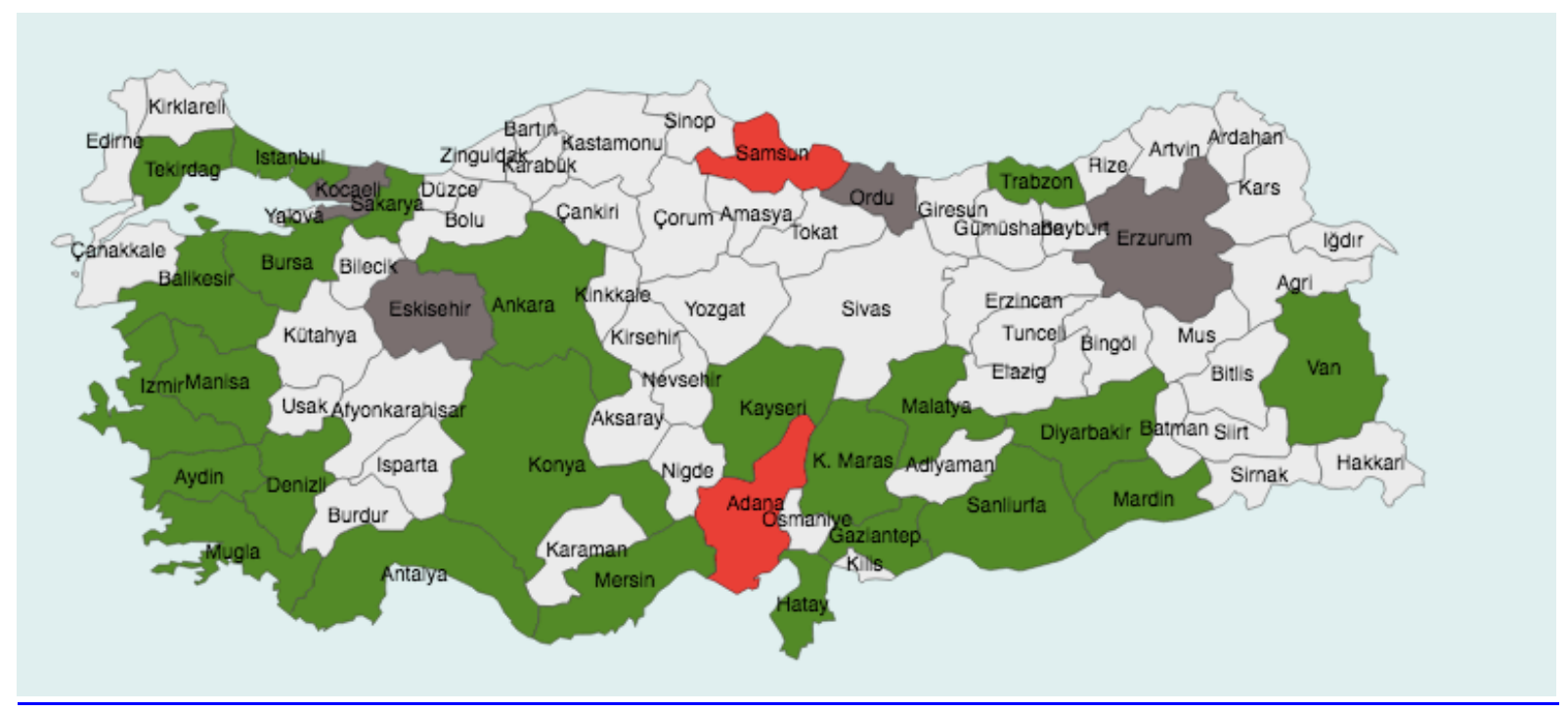

Map 2: Risk Map for the Metropolitan Municipalities in 2015

\subsection{The Review of 2016 Z'-Scores}

Z"-Scores of 2016 show that 3 of the 30 metropolitan municipalities were in financial distress (Red Area) whereas 6 municipalities were in the grey area and 21 municipalities were in the safe zone (Green Area). The risk map for 2016 is shown below. 


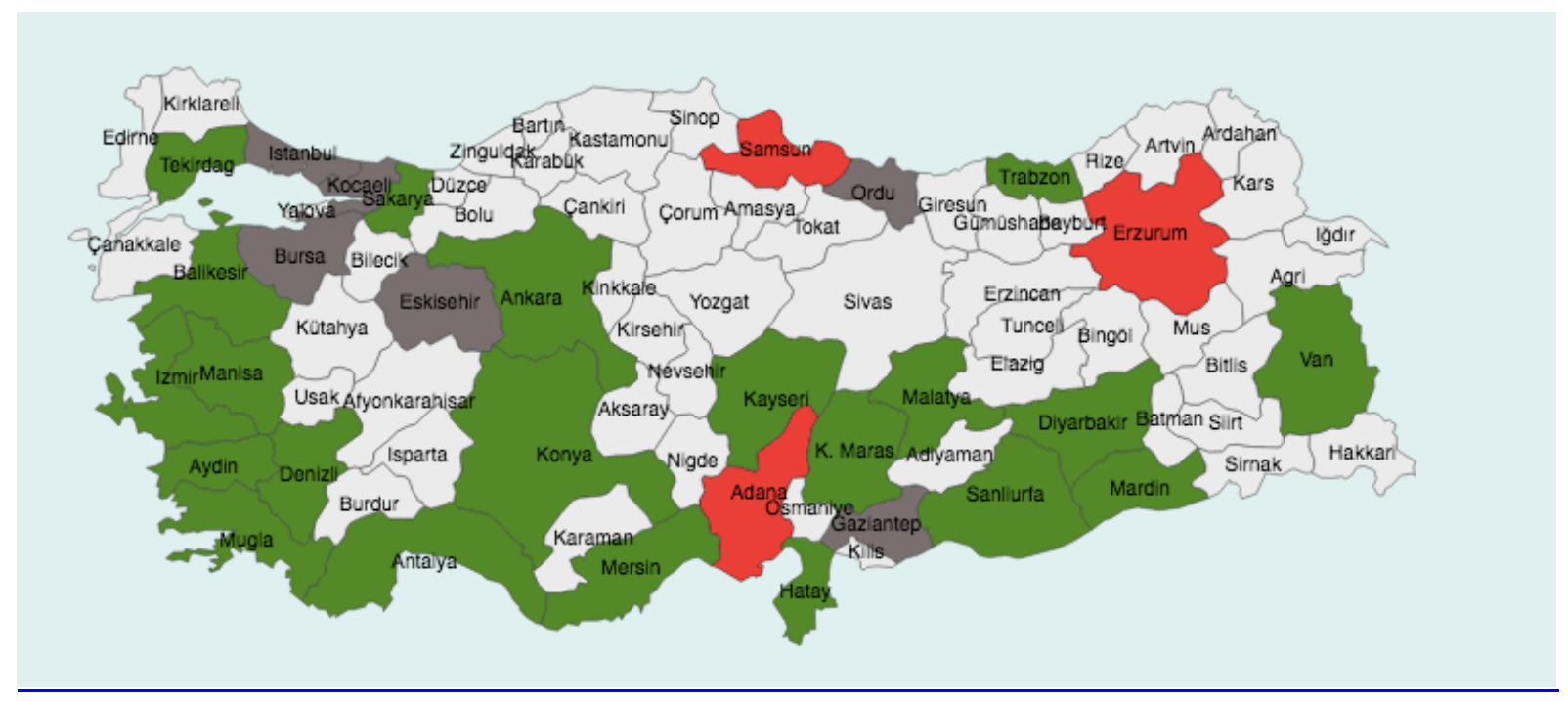

Map 3: Risk Map for the Metropolitan Municipalities in 2016

\subsection{The Review of 2017 Z"-Scores}

Z"-Scores of 2014 show that 4 of the 30 metropolitan municipalities were in financial distress (Red Area) whereas 3 municipalities were in the grey area and 23 municipalities were in the safe zone (Green Area). The risk map for 2017 is shown below.

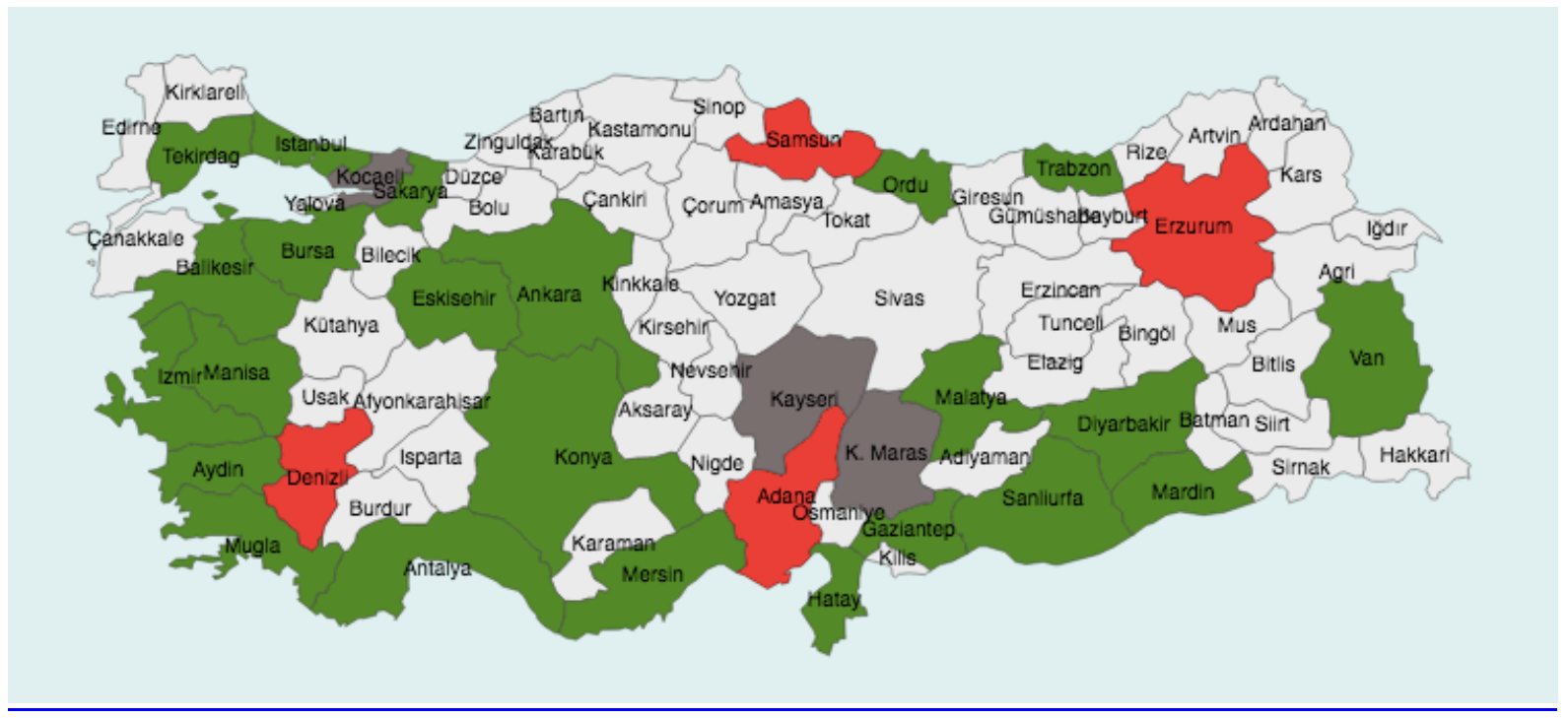

Map 4: Risk Map for the Metropolitan Municipalities in 2017

\section{Results}

The financial crises all around the world have underlined the importance of accounting-based financial distress prediction models. The financial failure or bankruptcy risk of a firm leaves all the partners in a tight sport. Therefore, the financial distress of municipalities, which are responsible for meeting public needs, leads to a decrease in high-quality services or lack of services, which may result in social problems. The performance of the municipalities with respect to efficiency and productivity at the micro-level will have an impact on the country's performance at the macro-level.

The results of the current study show that financil distress and bankruptcy prediction models used in private businesses can be used for municipalities as well, which emphasizes that the municipalities should take necessary precautions. The current study is the first one to evaluate the financial status of the metropolitan municipalities in Turkey using Altman's Z"'-Score, which is an accounting-based prediction model. Risk Maps for the Metropolitan Municipalities in Turkey were created based on the findings of the current study. The reason why the risk maps were created starting from the year 2014 is that the number of the metropolitan municipalities increased to 30 in 2014 with the enactment of municipality law. Based on the 6-year data, Z"- 
A. Kablan 12/1 (2020) 498-509

Scores for 30 metropolitan municipalities were calculated. The results showed that at least 2 and at the most 4 metropolitan municipalities were in the distress zone (Red Area) while at least 1 and at the most 5 metropolitan municipalities were in the grey zone. The rest of the municipalities were in the safe zone (Green Zone). The mean for the municipalities were quite high and they seemed to be in good condition.

In sum, although most of the metropolitan municipalities are in the safe zone, one might say that households do not trust them and some enterprises for bond issues backfired as stated in the reports. Despite the fact that government bonds are often seen as a reliable way of investment with low risk in addition to the results of the current study, it would be interesting to see what will be the future enterprises of the municipalities and how the households will react to bond issuance.

\section{Discussion}

Although the Z"'-Scores for the metropolitan municipalities are found to be quite high, it should be noted that accounting errors may be misleading for the statements and anaylises of the statements, which might be studied in future research. The Z"'-Scores of some municipalities which are up to 28 may result in errors in the statements.

The extent to which the municipalities take notice of the audit reports, that is whether they improve their accounting systems in line with the suggestions of the court of accounts, should be discussed in future research as reports show that the same or similar accounting errors have not been corrected in the following periods' financial statements.

Finally, in some countries around the world, bankruptcy is an option for municipalities. This may abolish the idea that central administration will always refrain the local administrative bodies from financial distress. So, the applicability of such a system in Turkey may also be investigated in future studies.

\section{References}

Altman, E.I., (1968). Financial Ratios, Discriminant Analysis and the Prediction of Corporate Bankruptcy, The Journal of Finance, 23, 4: 589-609

Altman, E., I. (2000). Predicting Financial Distress of Companies: Revisiting The Z-Score and Zeta Models, http://people.stern.nyu.edu/ealtman/Zscores.pdf, 02.10.2019.

Balaguer-Coll, M.T., D. Prior-Jimenez, J.M. Vela-Bargues (2002). Efficiency and Quality in Local Government Management: The Case of Spanish Local Authorities, Working Paper, Number 2/2012, Barcelona: Universitat Autònoma de Barcelona.

Beaver, W. H. (1966). Financial Ratios as Predictors of Failures. Journal of Accounting Research, pp. 71-111.

Bemmann, M. (2005). Improving the Comparability of Insolvency Predictions, Dresden University of Technology, Faculty of Business Management and Economics, Working Report No:8

Cumhur, Y. (2015). Türkiye'deki Il Belediyelerinin Etkinliğinin Belirlenmesi, Hacettepe Üniversitesi, Maliye Anabilim Dalı, Yayınlanmamış Doktora Tezi

Fisher, M., Marsh, T., Bunn, E., (2015). Fiscal Health Analysis of Texas And Its Municipalities, Journal of BusinessEEconomics Research, Second Quarter, Vol 13, Number 2, 115-122 https://clutejournals.com/index.php/IBER/article/view/9180

Gunnlaugsson, S.B. (2017). Credit Risk of Icelandic Municipalities, Oradea Journal of Business and Economics, $\begin{array}{llll}\text { Vol II, } & \text { Issue } & 2, & 8-15\end{array}$ https://www.researchgate.net/publication/324058970 CREDIT RISK OF ICELANDIC MUNICIPA LITIES

Hauschild, D. (2013). Altman Z-Score: Not Just for Bankruptcy: From Z-Score to Green Zone, Survivability, Amros Corporation.

Hayes, S. K., Hodge, K. A., \& Hughes L. W. (2010). A study of the efficacy of Altman's Z to predict bankrupcty of specialty retail firms doing business in contemporary times, Economics \& Business Journal: Inquiries 
\& Perspectives , 3(1). https://nebeconandbus.org/journal/EB]I2010HayesHodgeHughes.pdf, (02.11.2019)

Hergüner, B., (2017). Yeni Büyükşehir Belediyelerinin Hizmet Kalitesine Etkisinin Değerlendirilmesi: Trabzon'dan Bir Vaka Çalışması, Uluslararası Yönetim İktisat ve İşletme Dergisi, Vol 13, No 3, 631-642

https://www.blogarti.com/turkiyenin-buyuksehirleri.html

https://www.sayistay.gov.tr/tr/?p=2\&CategoryId=103

https://yerelyonetimler.csb.gov.tr, (05/10/2019)

Kulalı, İ. (2014). Muhasebe Temelli Tahmin Modelleri Işığında, Finansal Sıkıntı ve İflasın Karşılaştırılması, Sosyoekonomi, Temmuz-Aralık

Mahdi, Salehi \& Bizhan Abedini (2009). Financial Distress Prediction in Emerging Market: Empirical Evidences from Iran, Business Intelligence Journal, August, 2009 Vol. 2, No. 2, https://pdfs.semanticscholar.org/0d5e/6fecdfb450316bf1df89b820406922753835.pdf, (03.10.2019)

Michailov, A., M. Tomova, P. Nenkova (2002). Cost Effiency in Bulgarian Municipalities, 10th NISPAcee Annuel Conference, 25-27 April, Cracow.

Miller, W. (2009). Introducing the Morningstar Solvency Score, A Bankruptcy Prediction Metric http://ssrn.com/abstract=1516762，(01.11.2019).

Outecheva, Natalia (2007). Corporate Financial Distress: An Empirical Analysis of Distress Risk, Dissertation no. 3430, the University of St.Gallen Graduate School of Business Administration, Economics, Law and Social Sciences

(HSG),

http://www1.unisg.ch/www/edis.nsf/SysLkpByIdentifier/3430/\$FILE/dis3430.pdf (02.11.2019)

Özdemir, F.S. (2014). Halka Açık ve Halka Açık Olmayan İşletmeler Yönüyle Tekdüzen Muhasebe Sistemi ve Altman Z Skor Modellerinin Uygulanabilirliği, Ege Akademik Bakış, Cilt 14, Sayı 1, 147-161

Ross, S.A., Westerfield, R. W. ve Jaffe, J. (2005). Corporate Finance,6. Bask1, Irwin, McGraw-Hill.

Sakız, B. (2017). Finansal Oranlar Kullanılarak Risk Yönetimi ve Havayolu Sektörü - Bir Uygulama, International Conference on Eurasian Economies, Session 4B Finans II, 282-290

Sayılgan, Güven (2008). İşletme Finansmanı, Turhan Kitabevi, Ankara.

Unercoffer, R. (2013). Altman's Z-Score, Municipal Default, and Hedge Fund Strategy: A Case Study of Detroit, Michigan,https://www.academia.edu/27985523/Altmans ZScore Municipal Default and Hedge Fu nd Strategy A Case Study of Detroit Michigan, (05.10.2019)

1982 Türkiye Cumhuriyeti Anayasası (1982, 18 Ekim). Resmi Gazete (Sayı: 17863 (Mükerrer)). Erişim adresi: https://www.mevzuat.gov.tr/MevzuatMetin/1.5.2709.pdf

5393 Sayılı Belediye Kanunu (2005, 3 Temmuz). Resmi Gazete (Sayı: 25874). Erişim adresi: https://www.mevzuat.gov.tr/MevzuatMetin/1.5.5393.pdf

5216 Büyükşehir Belediyesi Kanunu (2004, 10 Temmuz). Resmi Gazete (Sayı: 25531). Erişim adresi: https://www.mevzuat.gov.tr/MevzuatMetin/1.5.5216.pdf

3030 sayılı Büyük Şehir Belediyelerinin Yönetimi Hakkında Kanun Hükmünde Kararnamenin Değiştirilerek Kabulü Hakkında Kanun (1984, 27 Haziran). Resmi Gazete (Sayı: 18453). Erişim adresi: https://www.tbmm.gov.tr/tutanaklar/KANUNLAR KARARLAR/kanuntbmmc067/kanuntbmmc067 Kkanuntbmmc06703030.pdf

6360 sayılı On Üç İlde Büyükşehir Belediyesi Kurulması ile Bazı Kanun ve Kanun Hükmünde Kararnamelerde Değişiklik Yapılmasına Dair Kanun (2012, 12 Kasım). Resmi Gazete (Sayı: 28489). Erişim adresi: www.mevzuat.gov.tr > MevzuatMetin > 1.5.6360.doc 